\title{
CORRELATIONS BETWEEN SOMATOTYPES AND NUTRITIONAL INTAKE IN MEMBERS OF A FITNESS STUDIO
}

\author{
Christoph Raschka, JoAnna Graczyk \\ Institute of Sports Sciences, Julius Maximilians University Würzburg, Germany
}

\begin{abstract}
This explorative study investigates the correlations between nutritional intake (macronutrient) and somatotypes and other body constitutional types in 121

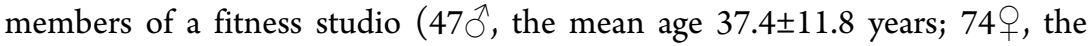
mean age $41.2 \pm 12.6$ years). Anthropometric data and computed constitutional and somatotypical parameters correspond to international standards. Nutrient intakes were estimated by the use of 3-day dietary recall records. The correlations between individual somatotypes and nutritional intake were generally weak, with only a few significant relationships identified.

In women the Plastic-Index after Conrad was positively related to protein intake $(r=0.28)$, the Metric-Index was positively related to fat intake $(r=0.22)$ and the energy intake $(r=0.25)$. In men the Plastic-Index after Conrad was positively correlated to the water intake $(r=0.38)$. In women Ectomorphy after Parnell was positively correlated to the energy intake ( $r=0.23)$, Endomorphy after Heath\&Carter was inversely related to the carbohydrate intake $(r=-0.19)$ and the energy intake $(r=-0.24)$. In women Mesomorphy after Heath\&Carter was inversely related to the carbohydrate intake $(r=-0.21)$ and the energy intake $(\mathrm{r}=-0.22)$. In women Pycnomorphy after Knußmann was positively correlated to the protein intake $(r=0.23)$ and Macrosomia after Knußmann was positively correlated to the protein intake. In men the Makrosomia after Knußmann was positively correlated to the protein intake $(r=0.26)$, carbohydrate intake $(\mathrm{r}=0.31)$, the energy intake $(\mathrm{r}=0.34)$ and the water intake $(\mathrm{r}=0.40)$.

The results indicate that differences may exist between the sexes in these correlations. Therefore it requires further follow-up studies to clarify these issues.
\end{abstract}

Keywords: somatotypes, nutritional intake 


\section{INTRODUCTION}

It is well established that diet influences the body composition and certain anthropometric parameters. There is also evidence of an association between the physique and nutritional status. Tanner et al. (1960) and Gordon et al. (1987) demonstrated a relationship between total serum cholesterol and the somatotype. Both studies revealed that endomorphs had the highest, whereas ectomorphs had the lowest serum cholesterol concentrations; men, but not women, exhibited this relationship. On the other side, there are only limited data evaluating the relationship between somatotypes and the nutritional intake.

So the present explorative study investigates the correlations between the nutritional intake (macronutrient) and somatotypes and other body constitutional types in the members of a fitness studio.

\section{PARTICIPANTS AND METHODS}

In this study 121 members of a fitness studio ( $47 \hat{\sigma}$, the mean age $37.4 \pm 11.8$ years, the height $180.4 \pm 7.2 \mathrm{~cm}$, the weight $80.4 \pm 10.6 \mathrm{~kg} ; 749$, the mean age $41.2 \pm 12.6$ years, the height $166.7 \pm 5.2 \mathrm{~cm}$, the weight $65.0 \pm 11.3 \mathrm{~kg}$ ) were examined. Each proband participated voluntarily and the data were used anonymously.

The anthropometric data and computed constitutional and somatotypical parameters in this work correspond to international standards (Conrad 1963, Heath \& Carter 1967+1990, Knussmann 1996, Martin \& Knussmann 1988, Raschka 2006, Tittel \& Wutscherk 1972). Nutrient intakes were estimated by the use of self-reported, 3-day dietary recall records of food and beverage consumption. The records (macronutrient) were quantified by means of the Tanita Health \& Food Manager software program. The analysis of differences was tested by ANOVA, correlations were tested by the Pearson correlation coefficients.

\section{RESULTS}

The distribution of constitutional types after Conrad and Knussmann and the somatotypes after Parnell and Heath \& Carter are summarized in Figures 1-4. 
The nutritional intake (macronutrient) of both genders and the correlation coefficients after Pearson between constitutional types / somatotypes and nutritional intake are shown in Tables 1-3.

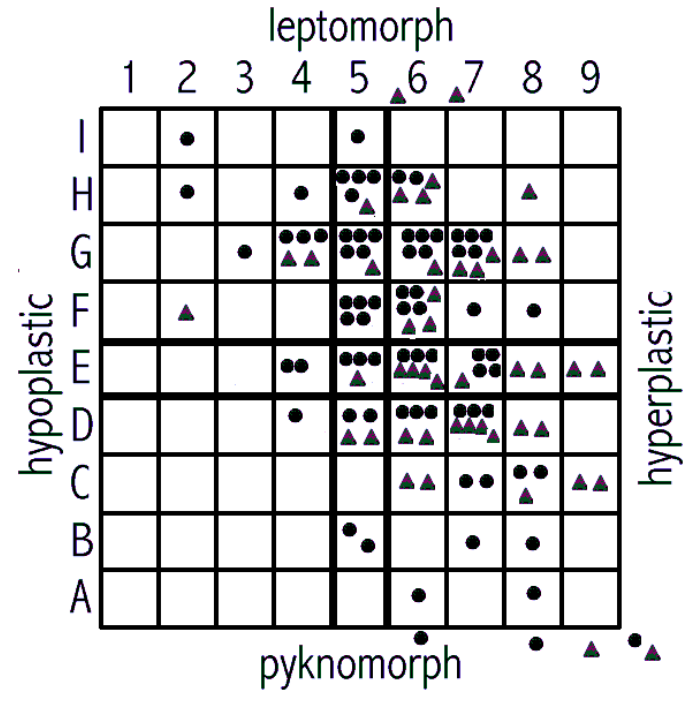

Figure 1. Male (triangles; $n=47$ ) and female (circles; $n=74$ ) members of the fitness studio in the chessboard pattern graphic after CONRAD

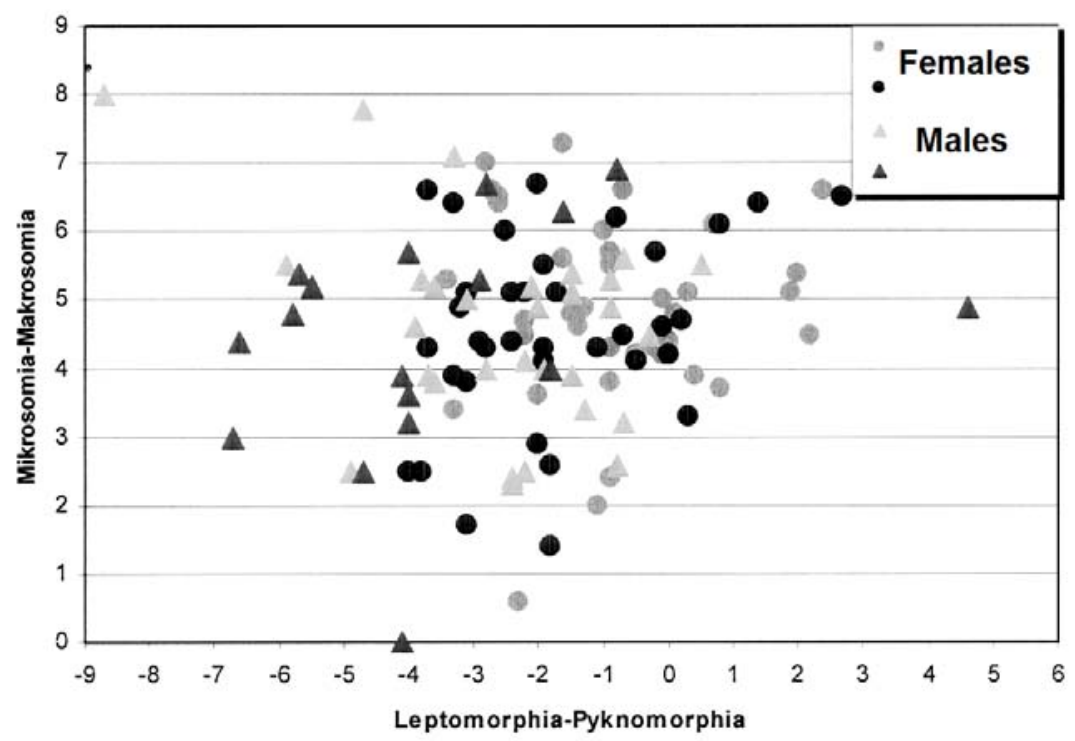

Figure 2. Male (triangles; $n=47$ ) and female (circles; $n=74$ ) members of the fitness studio in the system of the constitution types after KNUSSMANN 


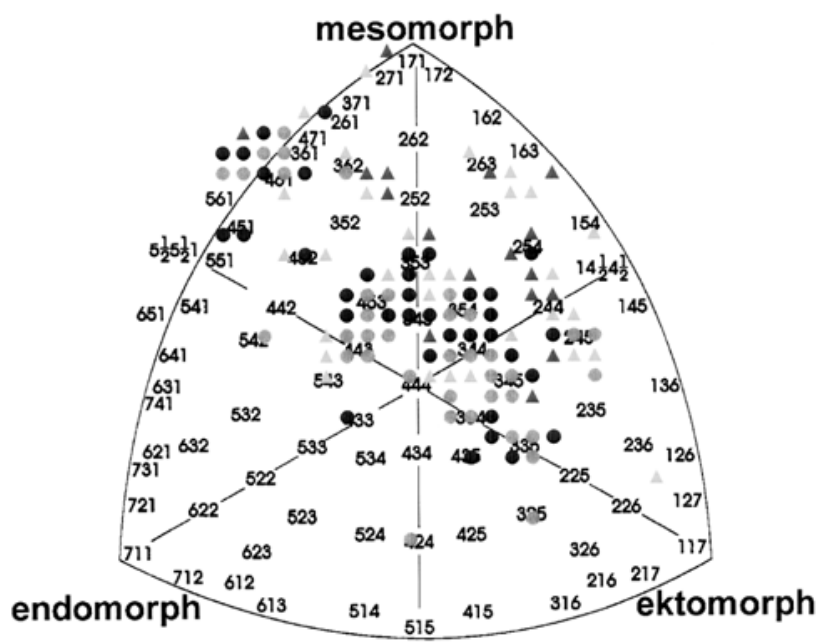

Figure 3. Male

(triangles; $n=47$ ) and female (circles; $n=74$ ) members of the fitness studio in the somatochart after PARNELL

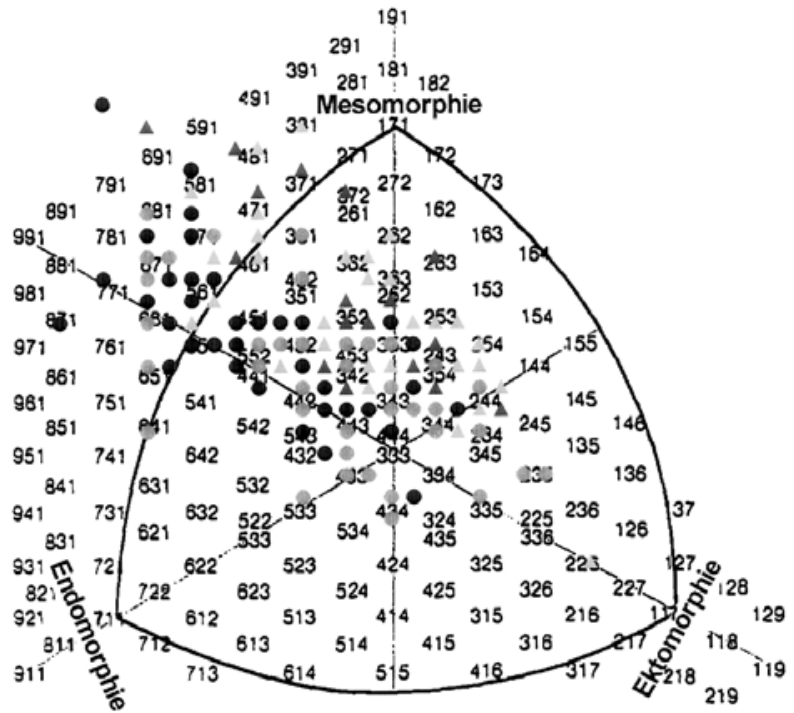

Figure 4. Male (triangles; $n=47$ ) and female (circles; $\mathrm{n}=74$ ) members of the fitness studio in the somatochart after HEATH and CARTER 
Table 1. Nutritional intake (macronutrient) of both genders

\begin{tabular}{lccccc}
\hline $\begin{array}{l}\text { Nutritional } \\
\text { Intake }\end{array}$ & $\begin{array}{c}\text { Protein } \\
(\mathbf{g} / \mathbf{d})\end{array}$ & $\begin{array}{c}\text { Fat } \\
(\mathbf{g} / \mathbf{d})\end{array}$ & $\begin{array}{c}\text { Carbohydrates } \\
(\mathbf{g} / \mathbf{d})\end{array}$ & $\begin{array}{c}\text { Energy } \\
(\mathbf{k c a l} / \mathbf{d})\end{array}$ & $\begin{array}{c}\text { Water } \\
(\mathbf{m l} / \mathbf{d})\end{array}$ \\
\hline $\begin{array}{l}\text { Women } \\
(\mathrm{n}=74)\end{array}$ & $61.4 \pm 16.0$ & $61.8 \pm 24.7$ & $195.2 \pm 51.9$ & $1664.2 \pm 383.3$ & $3175.0 \pm 1048.9$ \\
\hline Men $(\mathrm{n}=47)$ & $92.8 \pm 32.3$ & $80.0 \pm 30.7$ & $282.4 \pm 101.6$ & $2367.1 \pm 796.2$ & $3412.3 \pm 1175.9$ \\
\hline
\end{tabular}

Table 2. Correlations between constitutional parameters and the nutritional intake for the women

\begin{tabular}{|c|c|c|c|c|c|}
\hline $\mathbf{R}$ & $\begin{array}{l}\text { Protein } \\
\text { intake }\end{array}$ & $\begin{array}{c}\text { Fat } \\
\text { intake }\end{array}$ & $\begin{array}{l}\text { Carbohy- } \\
\text { drate } \\
\text { Intake }\end{array}$ & $\begin{array}{l}\text { Energy } \\
\text { Intake }\end{array}$ & $\begin{array}{l}\text { Water } \\
\text { Intake }\end{array}$ \\
\hline $\begin{array}{l}\text { Plastik-Index after } \\
\text { Conrad }\end{array}$ & $0.28 p<0.01$ & -0.06 n.s. & -0.14 n.s. & -0.07 n.s. & 0.03 n.s. \\
\hline $\begin{array}{l}\text { Plastik-Index with } \\
\text { correction for age }\end{array}$ & $0.23 p<0.05$ & -0.12 n.s. & -0.13 n.s. & -0.11 n.s. & 0.05 n.s. \\
\hline $\begin{array}{l}\text { Metrik-Index after } \\
\text { Conrad }\end{array}$ & -0.07 n.s. & $0.19 p<0.05$ & 0.16 n.s. & $0.25 p<0.05$ & $\begin{array}{l}-0.001 \\
\text { n.s. }\end{array}$ \\
\hline $\begin{array}{l}\text { Metrik-Index after } \\
\text { correction for age }\end{array}$ & -0.13 n.s. & $0.22 p<0.05$ & 0.14 n.s. & $0.24 p<0.05$ & -0.01 n.s. \\
\hline $\begin{array}{l}\text { Pyknomorphy } \\
\text { after Knußmann }\end{array}$ & $0.23 p<0.05$ & -0.12 n.s. & -0.03 n.s. & -0.10 n.s. & 0.12 n.s. \\
\hline $\begin{array}{l}\text { Makrosomia after } \\
\text { Knußmann }\end{array}$ & $0.28 p<0.01$ & -0.05 n.s. & -0.09 n.s. & -0.02 n.s. & 0.14 n.s. \\
\hline $\begin{array}{l}\text { Endomorphy after } \\
\text { Parnell }\end{array}$ & 0.01 n.s. & -0.07 n.s. & -0.12 n.s. & -0.16 n.s. & -0.04 n.s. \\
\hline $\begin{array}{l}\text { Mesomorphy after } \\
\text { Parnell }\end{array}$ & 0.01 n.s. & -0.11 n.s. & -0.12 n.s. & -0.18 n.s. & -0.05 n.s. \\
\hline $\begin{array}{l}\text { Ectomorphy after } \\
\text { Parnell }\end{array}$ & -0.05 n.s. & 0.19 n.s. & 0.14 n.s. & $0.23 p<0.05$ & 0.05 n.s. \\
\hline $\begin{array}{l}\text { Endomorphy after } \\
\text { Heath\&Carter }\end{array}$ & 0.04 n.s. & -0.14 n.s. & $-0.19 p<0.05$ & $-0.24 p<0.05$ & -0.11 n.s. \\
\hline $\begin{array}{l}\text { Mesomorphy after } \\
\text { Heath\&Carter }\end{array}$ & 0.02 n.s. & -0.10 n.s. & $-0.21 p<0.05$ & $-0.22 p<0.05$ & -0.10 n.s. \\
\hline $\begin{array}{l}\text { Ectomorphy after } \\
\text { Heath\&Carter }\end{array}$ & 0.01 n.s. & 0.14 n.s. & 0.19 n.s. & 0.19 n.s. & 0.11 n.s. \\
\hline
\end{tabular}


Table 3. Correlations between constitutional parameters and the nutritional intake for the men

\begin{tabular}{|c|c|c|c|c|c|}
\hline $\mathbf{R}$ & $\begin{array}{c}\text { Protein } \\
\text { intake }\end{array}$ & $\begin{array}{c}\text { Fat } \\
\text { intake }\end{array}$ & $\begin{array}{c}\text { Carbohydrate } \\
\text { Intake }\end{array}$ & $\begin{array}{l}\text { Energy } \\
\text { Intake }\end{array}$ & $\begin{array}{l}\text { Water } \\
\text { Intake }\end{array}$ \\
\hline $\begin{array}{l}\text { Plastik-Index after } \\
\text { Conrad }\end{array}$ & 0.14 n.s. & 0.12 n.s. & 0.19 n.s. & 0.24 n.s. & $0.38 p<0.01$ \\
\hline $\begin{array}{l}\text { Plastik-Index with } \\
\text { correction for age }\end{array}$ & 0.12 n.s. & 0.12 n.s. & 0.14 n.s. & 0.21 n.s. & $0.39 p<0.01$ \\
\hline $\begin{array}{l}\text { Metrik-Index after } \\
\text { Conrad }\end{array}$ & -0.03 n.s. & 0.08 n.s. & 0.12 n.s. & 0.03 n.s. & -0.21 n.s. \\
\hline $\begin{array}{l}\text { Metrik-Index after } \\
\text { correction for age }\end{array}$ & 0.01 n.s. & 0.14 n.s. & 0.18 n.s. & 0.11 n.s. & -0.11 n.s. \\
\hline $\begin{array}{l}\text { Pyknomorphy } \\
\text { after Knußmann }\end{array}$ & -0.09 n.s. & -0.10 n.s. & -0.15 n.s. & -0.10 n.s. & -0.02 n.s. \\
\hline $\begin{array}{l}\text { Makrosomia after } \\
\text { Knußmann }\end{array}$ & $\begin{array}{c}0.26 \\
p<0.05\end{array}$ & 0.19 n.s. & $0.31 p<0.05$ & $\begin{array}{c}0.34 \\
p<0.05\end{array}$ & $0.40 p<0.01$ \\
\hline $\begin{array}{l}\text { Endomorphy after } \\
\text { Parnell }\end{array}$ & 0.01 n.s. & -0.07 n.s. & -0.14 n.s. & -0.10 n.s. & -0.17 n.s. \\
\hline $\begin{array}{l}\text { Mesomorphy after } \\
\text { Parnell }\end{array}$ & 0.07 n.s. & 0.16 n.s. & 0.14 n.s. & 0.17 n.s. & 0.15 n.s. \\
\hline $\begin{array}{l}\text { Ectomorphy after } \\
\text { Parnell }\end{array}$ & 0.06 n.s. & 0.05 n.s. & 0.15 n.s. & 0.10 n.s. & 0.02 n.s. \\
\hline $\begin{array}{l}\text { Endomorphy after } \\
\text { Heath\&Carter }\end{array}$ & 0.002n.s. & -0.04 n.s. & -0.13 n.s. & -0.07 n.s. & -0.11 n.s. \\
\hline $\begin{array}{l}\text { Mesomorphy after } \\
\text { Heath\&Carter }\end{array}$ & 0.09 n.s. & 0.08 n.s. & 0.03 n.s. & 0.11 n.s. & 0.14 n.s. \\
\hline $\begin{array}{l}\text { Ectomorphy after } \\
\text { Heath\&Carter }\end{array}$ & 0.04 n.s. & 0.08 n.s. & 0.14 n.s. & 0.09 n.s. & -0.03 n.s. \\
\hline
\end{tabular}

\section{DISCUSSION}

Correlations between individual somatotypes of constitutional types after Conrad or Knussmann and the nutritional intake in the fitness studio collective were generally weak, with only a few significant relationships identified:

1. In women the Plastic-Index after Conrad (with and without correction for age) was positively related to the protein intake $(r=0.28)$, the Metric-Index after Conrad (with and without correction for age) was positively related to the fat intake $(\mathrm{r}=0.22)$ and the energy intake $(\mathrm{r}=0.25)$. In men the PlasticIndex after Conrad (with and without the correction for age) was positively correlated to the water intake $(\mathrm{r}=0.38)$.

2. In women Ectomorphy after Parnell was positively correlated to the energy intake ( $r=0.23$ ), Endomorphy after Heath\&Carter was inversely related to the carbohydrate intake $(r=-0.19)$ and the energy intake $(r=-0.24)$. In 
women Mesomorphy after Heath\&Carter was inversely related to the carbohydrate intake $(r=-0.21)$ and the energy intake $(r=-0.22)$. No significant relationships were found between somatotype rankings and the nutrient intake for men.

These findings for somatotypes are in partial agreement with the results of Bolonchuk et al. (2000) who examined somatotypes and the nutritional status of 63 men, ages 18-40, years who had been recruited for participation in studies to determine nutrient requirements in North Dakota. In this study Endomorphy was inversely related to the carbohydrate intake $(r=-0.294$, $\mathrm{p}<0.05)$. In contrast Mesomorphy was directly correlated with fat intake ( $\mathrm{r}=0.286, \mathrm{p}<0.05$; Bolonchuk Et al. 2000).

Raschka et al. (1993) investigated the correlations between the nutritional intake and the body build in 50 ultra long distance runners (42 sportsmen and 13 sportswomen), who participated in a $1000 \mathrm{~km}$-race, daily running $50 \mathrm{~km}$. In this collective Endomorphy after Heath\&Carter was negatively correlated to the energy intake $(r=-0.6, p<0.001$, the carbohydrate intake $(\mathrm{r}=-0.5, \mathrm{p}<0.001)$ and the fat intake $(\mathrm{r}=-0.4, \mathrm{p}<0.001)$, and Endomorphy after Parnell was inversely correlated to the energy intake $(\mathrm{r}=-0.4, \mathrm{p}<0.001)$, the carbohydrate intake $(\mathrm{r}=-0.4)$ and the fat intake $(\mathrm{r}=-0.3, \mathrm{p}<0.01)$.

3. In women Pycnomorphy after Knußmann was positively correlated to the protein intake $(\mathrm{r}=0.23)$ and Macrosomia after Knußmann was positively correlated to the protein intake.

In men Makrosomia after Knußmann was positively correlated to the protein intake $(\mathrm{r}=0.26)$, the carbohydrate intake $(\mathrm{r}=0.31)$, the energy intake $(\mathrm{r}=0.34)$ and the water intake $(\mathrm{r}=0.40)$. Similar relationships between Macrosomia after Knußmann and the nutritional intake were found by RASCHKA et al. (1993) in ultra long distance runners. In this study Macrosomia correlated positively with the energy intake $(r=0.6, p<0.001)$, the carbohydrate intake $(\mathrm{r}=0.5, \mathrm{p}<0.001)$, the protein intake $(\mathrm{r}=0.5, \mathrm{p}<0.001)$, the fat intake $(\mathrm{r}=0.5, \mathrm{p}<0.001)$ and the water intake $(\mathrm{r}=0.6, \mathrm{p}<0.001)$.

In summary, there are various studies revealing moderate to weak correlations between the different types of constitution and the supply of macronutrients. The results indicate that differences may exist between the sexes in these correlations. Therefore it requires further follow-up studies to clarify these issues. 


\title{
REFERENCES
}

1. Bolonchuk W., Siders W. A., Lykken G. I., Lukaski H. C. (2000). Association of dominant somatotype of men with body structure, function during exercise, and nutritional assessment. Am J Human Biology 12, 167-180.

2. Conrad K. (1963). Der Konstitutionstypus. Berlin. Springer Verlag

3. Gordon E., Tobias P. V., Mendelsohn D., Seftel H., Howson A. (1987). The relationship between somatotype and serum lipids in male and female young adults. Hum Biol 59, 459-465.

4. Heath B. H., Carter L. J. E. (1967). A modified somatotype method. Am J Phys Anthrop 27, 57-74.

5. Heath B. H., Carter L. J. E. (1990). Somatotyping - development and applications. Cambridge Studies in Biological Anthropology. Great Britain: Redwood Press.

6. Knußmann R. (1996). Vergleichende Biologie des Menschen. Lehrbuch der Anthropologie. Stuttgart: Gustav Fischer Verlag.

7. Kretschmer E. (1921). Körperbau und Charakter. Berlin. Springer Verlag.

8. Martin R., Knussmann R. (1988). Anthropologie. Handbuch. Band I. Stuttgart. Fischer Verlag

9. Parnell R. W. (1954) Somatotyping by physical anthropometry. Am J Phys Anthrop 12, 209-239.

10. Raschka C. (2006). Sportanthropologie. Köln. Sportverlag Strauß.

11. Raschka C., Plath M., Bernhard W., Jung K., Leitzmann C. (1993). Über die Beziehungen zwischen Nährstoffzufuhr und Konstitutionstyp, am Beispiel eines Langstreckenläuferkollektivs. Homo 44, 278-283.

12. Tanner J. M., Israelson W. J., Whitehouse R. H. (1960). Physique and body composition as factors affecting success in different athletic events. J Sports Med Phys Fit 14, 397-411.

13. Tittel K., Wutscherk H. (1972). Sportanthropometrie. Leipzig. Barth.

\author{
Adress for correspondence \\ Christoph Raschka \\ Institute of Sports Sciences \\ Julius-Maximilians-University \\ Judenbühlwegn 11 D-97082 Würzburg, Germany \\ E-mail: christoph.raschka@uni-wuerzburg.de
}

